\title{
REGIONAL AUTONOMY POLITICAL POLITICS OF REGIONAL LIABILITY REPORTS TO REGIONAL REPRESENTATIVES IN THE IMPLEMENTATION OF LOCAL GOVERNMENT
}

\author{
Cynthia Hadita \\ Master of Law Program, University of North Sumatra \\ cynthiahadita@gmail.com
}

\begin{abstract}
Regional autonomy can not be separated from political power, including the dynamics of the revision of relevant legislation pertaining to local government information report liability regional head for legislature. However, it is necessary to study the politics of regional autonomy through legislation that can provide only partial or partial benefits. The issue to be discussed is concerning the politics of regional autonomy law and its implications related to the report on the responsibility of the regional head to the regional legislative assembly. The research method used is normative juridical. The results showed that (1) the administration of regional government is related to the 5th precepts of Pancasila, Article 18 of the 1945 Constitution of the Republic of Indonesia, Article 71 of the Regional Government Law, which shows the dynamics of changes that are pragmatic and has substantial changes with the revision of the Regional Government Law. (2) The political implications of the regional autonomy law related to the report of the regional head are now only recommendation and corrective, but the regional people's representative council cannot easily overthrow the regional head that has been directly elected by the people.
\end{abstract}

Keywords: Politics, Regional autonomy, Implication.

Copyright@2020 NLR. All right reserved.

\section{INTRODUCTION}

Politics of law ${ }^{1}$ Regional autonomy related to the accountability statement (LKPJ) to the region to the Regional Representative Council (DPRD) has its own background. Because, prior to the latest law on regional government, the implications of LKPJ for regional heads that were not accepted by the DPRD could be dismissed in their terms of office. At present, the DPRD no longer has that authority. This is also related to legislative politics such as the dynamics of the revision of the regional government law into a regional autonomy law policy which is also closely related to power. Characteristics of a group of more

${ }^{1}$ Rules of Procedure (Republic of Indonesia Decree MPR number 7 / MPR / 2004 concerning Republic of Indonesia MPR Rules of Procedure as amended by Republic of Indonesia MPR Decree number 13 / MPR / 2004 concerning Amendments to Republic of Indonesia MPR Rules of Procedure), Nasution, Mirza., Politik Hukum dalam Sistem Ketatanegaraan Indonesia, (Medan: Puspantara, 2015), p. 9. 


\section{LAW REVIEW $\begin{aligned} & \text { E-ISSN: 2722-3663 } \\ & \text { Volume } 1 \text {, Issue 1, May 2020 }\end{aligned}$}

dominated or group political power (Ralf Dahrendorf) are: First, the number is always much smaller than the number of groups that are owned by the. Secondly, has the advantages of wealth specialized to remain maintai $\mathrm{n}$ its dominance, which is in the form of material wealth, intellectual, and honor morals. Third, the contradiction as better organized than the group who were subdued. Fourth, the ruling class consists only by those who hold the position of dominant in the field of politics, so the ruling elite is defined as the ruling elite in the political field. Fifth, the ruling class always tries to monopolize and bequeath its political power to its own class / group. Sixth, there is a reduction in social change to changes in the composition of the ruling class. $^{2}$

Political power is not only at the central level, but up to a unit of government structure smaller than that will not escape the contamination of political power. One at the level of ketatadaeraha $\mathrm{n}$, the provincial, district / city as between the regional administration and the DPRD head to spearhead the country's progress stemming from the implementation of good governance in a comprehensive manner.

The need to examine the politics of regional autonomy related to the regional head LKPJ to the DPRD and the implications of the change as something that leads to the direction of legal development that is better or not

\footnotetext{
${ }^{2}$ Ibid., p. 10.
}

and has conformity with the ideals and philosophy of life of the nation.

Based on the problems, the writer is interested to discuss with the article entitled "Politics Regional Autonomy Law Against Reports Accountability To the Regional Head of the Regional Representatives Council In the organization of Local Government".

\section{METHODOLOGY}

The method that is used is the study of law juridical normative by doing a search library ( library research) and use the data secondary. Juridical normative has sense to find the truth of coherence. ${ }^{3}$ The data are used , namely the data of secondary that includes abstract, index, bibliogra phy, publishing government, and mate rial references other. ${ }^{4}$ As for the substance of law that is used is as follows :

a. Primary legal material, that is legal material that is authoritative, means that it has authority. ${ }^{5}$

b. Secondary legal material, in the form of reading material that provides an explanation of the primary legal mate rial. It is not impossible as a guide to thinking in preparing arguments that will be submitted in court or providing legal opinion. ${ }^{6}$

3 Marzuki, Peter Mahmud., Penelitian Hukum, (Jakarta: Prenada Media Group, 2014), p. 47.

4 Soekanto, Soerjono., Penelitian Hukum Normatif, (Jakarta: PT Raja Grafindo, 2013), p. 29.

5 Marzuki, Peter Mahmud., Op, Cit., p. 181.

Wijayanti, Asri., Strategi Penulisan Hukum, (Bandung: Lubung Agung, 2011), p. 97. 


\section{LAW REVIEW $\begin{aligned} & \text { E-ISSN: 2722-3663 } \\ & \text { Volume } 1 \text {, Isue 1, May 2020 }\end{aligned}$}

c. Material law tertiary, namely by usin g a dictionary of law and dictionary general and website internet as material guidance or explanation of the material laws of primary and secondary.

The results of this study use qualitative analysis . Against the data with the analysis of qualitative is used when data is collected not in the form of figures that can do the measurement, the data are difficult to be measured by the numbers, the relationship between variables is not clear, the sample is to be nonprobability, the use - the use of the theory of less is required. ${ }^{7}$

\section{DISCUSSION}

The Politics of Regional Autonomy Law Related to Reports on the Accountability of Regional Heads To the Regional Representatives Council

Pancasila as the philosophy of life of the nation which is also the source of all legal sources has highdimensional values and is in accordance with the values that live in society, because Pancasila is also a national character that can distinguish Indonesian people from other nations so that Pancasila also becomes a reference against various rules which are then followed by the constitution and various other organic regulations.

The 5th precept "Social justice for all Indonesians", if interpreted, can be a fundamental foundation for the existence of rights and obligations between regional heads who provide

7 H, Philips Dillah, Suratman., Metode Penelitian Hukum, (Bandung: Penerbit Alfabeta, 2015), p. 145.
LKPJ to the DPRD to achieve justice for the people at the regional level in upholding transparency and accountability towards the implementation of regional government. The constitution as the highest legal rule in the hierarchy of statutory regulations in Indonesia explicitly regulates taxes as in Article 18 of the 1945 Constitution which reads as follows:

"The division of Indonesian regions into large and small regions with the form of government structure is determined by law, by looking at and keeping in mind the basis of consultation in the state government system and the rights of origin in special regions". 8

Relating to the material content in the context of accommodating the special conditions of the region, means that regional regulation as regulation that abstract society values that contain material content identified as special conditions of the region. Based on these contemplations, a territorial direction that does not apply or reflect formal andmaterial standards within the definition of a territorial control will notbe canceled in the event that there's nolossorpotential misfortune of a legitimate subject who submits an examination of territorial regulation.To guarantee compliancewith these standards, an expectant step is required

8 Indrati, Maria Farida., Ilmu Perundang-Undangan, (Yogyakarta: Kanisius, 1998), p. 85. 


\section{LAW REVIEW $\begin{gathered}\text { E-ISSN: 2722-3663 } \\ \text { Volume } 1 \text {, Issue 1, May 2020 }\end{gathered}$}

so that territorial regulationformulated by thecompetent educate stay steady in implementingthe standards of the definition oflegislation.Because the rule of law (in this setting the guideline of detailing of enactment) contains ameasure of esteem and as it were indirectly provides rules, the guideline of law isn't alwaysposited in therule oflaw, then it gets to be troublesome to implementit within the run the show of law. ${ }^{9}$

Furthermore, specifically regarding LKPJ regulated in Article 71 paragraph (1) of Law Number 23 of 2014 concerning Regional Government (UU Pemda) regulates that "Reports on accountability statements contain the results of the administration of Government Affairs carried out by Regional Governments. (2) The regional head submits the accountability statement as referred to in Article 69 paragraph (1) to the DPRD which is conducted 1 (one) time in 1 (one) year no later than 3 (three) months after the fiscal year ends. (3) The accountability statement to the DPRD as referred to in paragraph (2) shall be discussed by the DPRD for a recommendation to improve the administration of the Regional Government".

Law Number 9 Year 2015 concerning the Second Amendment to Law Number 23 Year 2014

9 Eka N.A.M. Sihombing, Eddy Purnama, Budiman Ginting, Faisal Akbar Nasution, The Regional Regulation Concerning Management Of Zakat Viewed From The Principles Of Formulation Of Legislation, International Journal of Advanced Science and Technology, Vol. 29, No. 6, (2020). concerning Regional Government, has not been amended by Article 71 governing LKPJ so that it is still with the same implementation to be enacted.

The legal policy on LKPJ before the latest Local Government Law is closely related to power, such as what the ruling government wants to regulate regarding the implementation of regional autonomy. Although regulating its own household affairs, but still the rules are based on the Law made by the government.

Power has a very important role because it can determine the fate of millions of people. Both the bad power must always be measured by its usefulness to achieve a goal that has been determined or realized by the community first. ${ }^{10}$

In general, people aspire that there is no difference in position and role in society. However, these ideals will fall into different realities. Every community must place its citizens in a certain place in the social structure and encourage them to carry out their obligations as a result of the placement. If all obligations are always in accordance with the wishes of the community members and according to their abilities, difficulties will not be encountered. ${ }^{11}$

The theory of power, Laski argues, along with Marx, namely that every association of life requires coercive instruments, thus claiming the continuation of a permanent

10 Soekanto, Soerjono., Pokokpokok Sosiologi Hukum, (Jakarta: PT RajaGrafindo Persada, 2006), p. 90,

${ }^{11}$ Ibid., p. 89. 


\section{LAW REVIEW $\begin{gathered}\text { E-ISSN: 2722-3663 } \\ \text { Volume } 1, \text { Issue 1, May 2020 }\end{gathered}$}

production relationship, because if it were not so then the association of life would not be able to claim its livelihood. By Plato in his book "Politeia" Thrasymachos statement noted, that justice is the interest of the powerful who demanded the arrangement to the power that is there, it means that the law and the interests of the ruling is one. ${ }^{12}$

The authoritarian political configuration, is the composition of the political system that allows the state to play a very active role and takes almost all initiatives in making state policy. This configuration is marked by the drive of the power elite to impose unity, the elimination of open opposition, the dominance of the state leadership to determine state policy, and the dominance of political power by the eternal political elite, and there is a doctrine that justifies the concentration of power. ${ }^{13}$

The role of the regional head is very large in the implementation of regional tasks, especially the autonomy tasks. In connection with this, a scholar stated, the success or failure of Regional tasks is highly dependent on the Regional Head as the Regional Manager concerned. Success does not have someone holding a position in carrying out their duties depending on the quality they have. Likewise, the Regional Head; the success or failure of him to

${ }^{12}$ Lubis, M, Solly., Ilmu Negara Edisi Revisi (Bandung: CV, Mandar Maju, 2014), p. 42, 13 , carry out his duties depends on the quality he has. ${ }^{14}$

Before Law No. 23 of 2014 which regulates LKPJ, in the deliberation of lawmakers when making changes to Law Number 22 of 1999, this deliberation is a form of government fear that the DPRD will no longer have the authority to carry out the oversight function. This has a direct effect on the accountability of local government administration, more specifically when it is associated with budget management. ${ }^{15}$

Political power has the characteristic of not wanting to be limited. Instead, the law has the characteristic of limiting everything through its rules. In the relationship between law and political power, law should limit political power, so there is no abuse of power and arbitrariness. ${ }^{16}$

The politics of regional autonomy law is so closely related to political power that this Law is the most frequently revised rule. Specifically the regulation regarding $L K P J$, there was a substantial change during the transition to the revision of Law No. 22 of 1999 so that the DPRD is reduced in authority in terms of supervision related

14 Kaho, Josef Riwu., Prospek Otonomi Daerah di Negara Republik Indonesia (Identifikasi Beberapa Faktor yang Mempengaruhi Penyelenggaraannya), (Jakarta: PT RajaGrafindo Persada, 1995), p. 64.

${ }^{15}$ Karianga, Hendra., Carut-Marut Pengelolaan Keuangan Daerah di Era Otonomi Daerah Perspektif Hukum dan Politik, (Depok: Kencana, 2017), p. 214,

16 Ali, Achmad., Menguak Tabir Hukum, (Jakarta: Prenadamedia Group, 2014), p. 84. 


\section{LAW REVIEW $\begin{aligned} & \text { E-ISSN: 2722-3663 } \\ & \text { Volume } 1, \text { Issue 1, May 2020 }\end{aligned}$}

to the LKPJ of the regional head which has implications for the implementation of the authority between the DPRD and the regional head.

Implications of Reports on the Accountability of Regional Heads To the Regional Representatives Council after the Revision of the Regional Government Law

The law, among others, creates the rights and obligations and their implementation. In this case, there are rights and obligations of community members that cannot be applied, because the person concerned does not have the power to implement them. But on the contrary, there are also rights which are automatically supported by power. Moreover, if the community recognizes the existence of certain rights, then this generally means that there is power to exercise these rights through certain legal institutions, because the law without the power to implement it is a dead law. This is due to the fact that law cannot be confirmed by relying solely on the existence of a written constitution or the tradition of the rule of law. To carry out this law enforcement, certain institutions whose authority is recognized are needed. ${ }^{17}$

Associated with the use of moral responsibility in the office, Roscoe Pound pointed out that in a society which people may assume that people who are on around him are people who civilized, as a result, in the event of an act that deviates would hold accountable the parties that did such 60. acts, as a result, in the view of Roscoe Pound there are four things that become the basis for applying the moral responsibility, namely: ${ }^{18}$

1. That other people will have the hope of

good and reasonable that created the appointment or conduct of the person's official;

2. That officials will keep its promise is based on the hope that is attached to it by a sense of morality on the citizens;

3. That they will act diligently and can be trusted in the interaction of position and work;

4. That they will refurbish anything that has accep tance

of error or circumstances which do not unexpectedly been acceptance of erroneous or circumstances that ar e not presumed - would have thought, so they accept anything that should not be worthy and not will be received in ordinary

circumstances.

That the enactment of Law no. 22 of 1999 (Republic of Indonesia State Gazette of 1999 No. 60) concerning Regional Government on 7 May 1999 has become the basis for the enactment of the New Political Law of Regional Autonomy including regulating the problem of Regional Regulation (Perda). ${ }^{19}$

Decentralized policy narratives articulated by donors tend to describe 163.

18 Karianga, Hendra., Op,cit., p.

${ }^{19}$ Nasution, Mirza., Op, Cit., p. 63. 


\section{LAW REVIEW $\begin{aligned} & \text { E-ISSN: 2722-3663 } \\ & \text { Volume } 1, \text { Issue 1, May 2020 }\end{aligned}$}

decentralization as a technical process of policy design and implementation, advocating decentralization as a solution to certain problems. ${ }^{20}$

The problem is phenomenal that although the amendments to the 1945 Constitution and the political changes in regional autonomy law have been repeatedly carried out, the reality is still normative and only rhetorical political policies. The rights of local people to autonomy in law and politics based on the values of local wisdom have become prisoners and castration by the legal politics of the State or the Indonesian government who are forced to apply positive law uniformly and centrally to the local without making more consideration of the plurality and multiculturality of the local legal community, and also ignores the value system of the existence of local wisdom and local laws that have specific, unique and superior characteristics. National law (modern law) has ignored local law which in fact has become effective evidence both in realizing social defense and in fact legal protection (order, peace, harmony, happiness, benefits, safety, welfare), and to solve many problems efficiently and effectively. ${ }^{21}$

According to Mardiasmo, there are three main aspects of the success of local government, namely monitoring,

${ }^{20}$ PaulFaguet, Jean., Decentralization and Governance, Elsevier, Vol, 53, (January 2014).

${ }^{21}$ Ilyas, Ilyas, a., A Study on Legal Autonomism Prospect Within Legal Political of Local Autonomy, Talent Development dan Excellence, Vol,12, No,3s, (2020). control and inspection. These three things are fundamentally different in both conception and application. Supervision refers to the level or activities carried out outside the executive, namely the community and the DPRD, to oversee government performance. Control is a mechanism carried out by the executive (local authority) to ensure that policies and management systems are implemented properly so that organizational goals can be achieved. An audit is an activity by a party that has independence and professional competence to check whether the results of local government performance are in accordance with existing standards or criteria. To avoid political corporations between Regional heads and DPR Representative heads or vice versa, the principle of "checks and balances" needs to be done to create a balance of oversight and authority that they have. Therefore, DPRD members can be said to have accountability, when they have professional "sense of responsibility" and "ability" in carrying out their roles and functions. ${ }^{22}$

In general, there are at least three assumptions that always arise about the function of the DPRD. First, the DPRD is considered less able to carry out its functions as a balanced and effective regional head partner. This

22 Sukadi, A., Gunarto, Soegianto, The Implementation Of Roles And Functions Of Regional House Of Representatives (DPRD) Based On Law State Framework To Achieve Good Governance, The 3rd International Conference and Call for Paper Faculty of Law 2017, Sultan Agung Islamic University, (2017). 


\section{LAW REVIEW $\begin{aligned} & \text { E-ISSN:2722-3663 } \\ & \text { Volume } 1 \text {, Isue 1, May 2020 }\end{aligned}$}

assumption is generally adopted by political observers who tend to assess the role of regional heads that are still quite dominant in the implementation of regional government. Second, the DPRD is considered to be too distracting in the area of duties of the regional head. ${ }^{23}$

The relationship between supervision with governance regions in essentially that the oversight is any business or activity for knowing and assessing the phenomenon that is actually about application tasks or activities, whether in sync with what should or not. Thus the manifestation is based on the performance of supervision is the activity for assessing an implementation in tasks de facto, whereas the purpose of monitoring it in essence is a media limited for doing some sort of crosschecking or matching if the activities are carried out b already appropriate use of benchmarks measure that has been affected previously or not, thus ju g a use follow up on the results of monitoring earlier. Between parliament using Regional Head has the interaction of supervision is the interaction that is owned either become members of Parliament and Parliament as an institution to the Head of Regional as a reflection by government that is democratic, using the intention that in the governance area does not deviate according to the norms and regulations and guidelines others are set along or th at outlined the government were higher.

${ }^{23}$ Ibid.
Then, according to the interaction of supervision had given birth a few rights, the request message to the head area, do watertight work with the head area or device area, held a meeting to hear the opinion by the head of the area, asking questions and the right to investigate, as well as site visits, and so forth. As a follow-up by the interaction of supervision it is the interaction of accountability. ${ }^{24}$

According to Teuku Mohammad Radhie, who during his lifetime served as the head of BPHN, in carrying out legal reform efforts there were at least three important things that needed attention: (1) his own law, (2) law enforcement officials, (3) legal awareness of the community as a whole as a whole. $^{25}$ With changes in philosophy, ideology, and perspective in society, what is meant is a very fundamental change in the pattern of people's views of everything that happens in everyday life. Society will be very chaotic when there is a change in philosophy, ideology, or perspective of society but not followed by a commensurate change in law. ${ }^{26}$

If the power incarnated in himself one or a group of people, then the person or persons had been named a leader (or leaders), while the agency is leadership. Leadership is

${ }^{24}$ Santoso, M, Agus., Peran Dewan

Perwakilan Rakyat Daerah Dalam Menjalankan Fungsi Pengawasan, Jurnal Hukum, Vol, 18, No, 4, (Oktober 2011).

${ }^{25}$ Ibid., p. 38-39.

${ }^{26}$ Fuady, M., Teori-Teori Dalam Sosiologi Hukum (Jakarta: Kecana, 2011), p. 57. 


\section{NOMOI}

\section{LAW REVIEW E-ISSN: 2722-3663

the result

of social

organizations that have been formed or as a result according

to social interaction. The emergence

of a leader is a process of moving forward in sync using the needs of group

life. If at the

time had not appeared someone a leader, it is likely the group was going to run into an integrated whole. Not the emergence of a leader that is possible by for individuals who are expected to be become a leader, it has not succeeded. ${ }^{27}$

In the view of adherents of Realism (realists), law is the result of social forces and social control tools. Therefore, the realist law program is almost unlimited, human personality, social environment, economic conditions, business interests, prevailing ideas, general emotions, all of these are shapers of law and the results of law in life. That is why, it is very true what is said by a prominent realist (Liewellyn), that the main thing in realist law is the movement in thinking and working on law. In another formula, Lieewellyn mentioned the formula of realism as follows: "Don't get your law from the rules, but get your rules from the law that is ". ${ }^{28}$

The view of legal realism ( legal realism ) comes from the view of neopositivism. The view that originated from the view of positivism which

${ }^{27}$ Soekanto, Soerjono., Kegunaan Sosiologi Hukum Bagi Kalangan Hukum (Bandung: Alumni, 1976), p. 58.

28 Aburaera, Sukarno., Muhadar, Filsafat Hukum: Teori dan Praktik, (Depok: Prenadamedia Group, 2018), p. 129-130. originated in empiricism that favor scientific science. Characters in positivism such as Jerremy Bentham, John Stuart Mill, Adolf Merkel, and John Austin avoid all remarks that cannot be scientifically justified. In the twentieth century began the development in which the view that knowledge is not a science cannot be trusted to cause philosophers to find a way out of the problem of knowledge by investigating the contents of understanding and language in depth. This is what distinguishes the view of neopositivism from the view of positivism in which the view of neopositivism gives greater attention to logic and to relations between the era of logic and language.

The characteristics of the approach used by juridical realists on legal matters are: ${ }^{29}$

1. An investigation into the specific elements contained in legal cases;

2. An awareness of irrational and illogical factors in the process of the birth of a court decision;

3. An evaluation of the rule of law through an evaluation of the consequences of applying the rule of law;

4. Shows law in relation to political, economic, and other factors.

It is unfortunate that the spirit of supervision possessed by the DPRD in Law Number 22 Year 1999 has been annulled by Law Number 32 Year 2004. In LPJ, the DPRD can reject the responsibility of the regional head; in LKPJ (Accountability Statement), the

${ }^{29}$ Ibid 


\section{LAW REVIEW $\begin{aligned} & \text { E-ISSN:2722-3663 } \\ & \text { Volume } 1 \text {, Isue 1, May 2020 }\end{aligned}$}

DPRD does not have the authority to refuse but only provides a corrective record of the administration of government by the regional head. ${ }^{30}$

In Law Number 22 Year 1999 before being amended by Law Number 32 Year 2004 local government accountability in budget management is conveyed to the DPRD in the form of LPJ (Accountability Report) and the DPRD is given full authority to conduct an assessment. The rejection of LPJ can result in regional heads being dismissed, because they cannot properly manage / administer the government. ${ }^{31}$

No matter how extensive the autonomy a region has, its implementation must remain within the framework of the Unitary State of the Republic of Indonesia. In addition, the implementation of autonomy must ensure a harmonious relationship between the community, the regional government and the DPRD. The performance of the implementation of regional autonomy, namely the Regional Government and DPRD, must always be oriented to improving welfare and services to the community by always paying attention to the interests and aspirations of the wider community. ${ }^{32}$

LKPJ was conveyed by the regional head in the Plenary Meeting. Then the DPRD is discussed internally according to the rules and

${ }^{30}$ Karianga, Hendra., Op,cit., p. 215.

${ }^{31}$ Ibid., p. 214.

32 Astomo, Putera., Hukum Tata

Negara Teori dan Praktek, (Yogyakarta: Thafa Media, 2014), p. 143-144. decisions of the DPRD. Then it is submitted no later than 30 after the LKPJ is received, and submitted to the regional head in a special Plenary Meeting, as a recommendation for improvement of the administration of the government that will come. If within 30 days the LKPJ is not responded to, it is considered that there are no recommendations for improvement. The results of the DPRD's discussion of the regional head LKPJ were determined in the DPRD's decision in the form of strategic notes and recommendations to be followed by the regional head in carrying out his duties. Records and recommendations include administrative, policy and legal matters. ${ }^{33}$

Previously, the DPRD could dismiss the regional head if the DPRD rejected its LKPJ which was not in line with national goals and strategies. But with the latest regional government regulation, the DPRD no longer has that authority. Now, the DPRD does not easily overthrow the regional head who has been directly elected by the people if it does not violate the ethics and legislation in force and there is still another long process to dismiss the regional head. At present, LKPJ is not appropriate, so the DPRD can only provide corrective recommendations to the report of the regional head in the administration of regional government. This change shows the

33 DPR , www, dpr,go,id, "LKPJ Regional Head To DPRD", accessed on 10 May (2020). 


\section{LAW REVIEW $\begin{aligned} & \text { E-ISSN:2722-3663 } \\ & \text { Volume } 1 \text {, Isue 1, May } 2020\end{aligned}$}

politics of law that leads to progressive national development legal efforts.

\section{CONCLUSION}

The politics of regional autonomy law is so closely related to political power that this Law is the most frequently revised rule. Specifically the regulation regarding LKPJ, there was a substantial change during the transition to the revision of Law No. 22 of 1999 so that the DPRD is reduced in authority in terms of supervision related to LKPJ regional heads by the DPRD. The political implications of regional autonomy law through the legislation, now the DPRD no longer has that authority. DPRD does not easily bring down regional heads that have been directly elected by the people. At present, LKPJ is not appropriate, so the DPRD can only provide corrective recommendations.

In the future, the politics of regional autonomy law for LKPJ must be innovative, although the DPRD can only provide corrective recommendations but there needs to be a sanction if the regional head does not improve the LKPJ or LKPJ is very far from the expectations of the community so that good governance is achieved. Through clean local government. There is also a positive impact, if the holders of power have legal awareness (legal awareness ) and also a high moral burden in carrying out their duties solely for the advancement of the territory under their control.

\section{REFERENCES}

Aburaera. S., Muhadar. Filsafat Hukum: Teori dan Praktik, Depok: Prenadamedia Group, 2018.

Ali. Achmad., Menguak Tabir Hukum, Jakarta: Prenadamedia Group, 2014.

Astomo. Putera., Hukum Tata Negara Teori dan Praktek, Yogyakarta: Thafa Media, 2014.

Dillah. Suratman H Philips., Metode Penelitian Hukum, Bandung: Penerbit Alfabeta, 2015.

DPR. "LKPJ Kepala Daerah Kepada DPRD”, $\quad$ www.dpr.go.id. accessed 10 May (2020).

Fuady. M., Teori-Teori Dalam Sosiologi Hukum, Jakarta: Kecana, 2011.

Ilyas, Ilyas, A., A Study on Legal Autonomism Prospect Within Legal Political of Local Autonomy, Talent Development dan Excellence, Vol.12. No.3s. (2020).

Indrati. MF., Ilmu PerundangUndangan, Yogyakarta: Kanisius. 1998.

Kaho. JR., Prospek Otonomi Daerah di Negara Republik Indonesia (Identifikasi Beberapa Faktor yang Mempengaruhi Penyelenggaraannya), Jakarta: PT RajaGrafindo Persada. 1995.

Karianga. H., Carut-Marut Pengelolaan Keuangan Daerah di Era Otonomi Daerah Perspektif Hukum dan Politik, Depok: Kencana, 2017. 


\section{LAW REVIEW $\begin{aligned} & \text { E-ISSN:2722.3663 } \\ & \text { Volume } 1, \text { Issue } 1 \text {, May } 2020\end{aligned}$}

Lubis. M. Solly., Ilmu Negara Edisi Revisi, Bandung: CV. Mandar Maju, 2014.

Marzuki. PM., Penelitian Hukum, Jakarta: Prenada Media Group, 2014.

Nasution. Mirza., Politik Hukum dalam Sistem Ketatanegaraan Indonesia, Medan: Puspantara, 2015.

PaulFaguet. F., Decentralization and Governance, Elsevier, Vol. 53. (January 2014).

Santoso. MA., Peran Dewan Perwakilan Rakyat Daerah Dalam Menjalankan Fungsi Pengawasan, Jurnal Hukum, Vol. 18. No. 4. (Oktober 2011).

Soekanto. Soerjono., Kegunaan Sosiologi Hukum Bagi Kalangan Hukum, Bandung: Alumni. 1976.

Penelitian Hukum Normatif, Jakarta: PT Raja Grafindo, 2013. Pokok-pokok Sosiologi Hukum, Jakarta: PT RajaGrafindo Persada, 2006.

Sukadi. A., Gunarto. Soegianto., The Implementation Of Roles And Functions Of Regional House Of Representatives (DPRD) Based On Law State Framework To Achieve Good Governance, The 3rd International Conference and Call for Paper Faculty of Law 2017, (2017).

Sihombing, Eka N.A.M., Eddy P, Budiman G, Faisal AN, The Regional Regulation Concerning Management Of Zakat Viewed From The Principles Of
Formulation Of Legislation, International Journal of Advanced Science and Technology, Vol. 29, No. 6, (2020).

Wijayanti. A., Strategi Penulisan Hukum, Bandung: Lubung Agung, 2011.

Law Number 22 of 1999 concerning Regional Government.

Law Number 32 of 2004 concerning Regional Government.

Law Number 23 of 2014 concerning Regional Government.

Law Number 9 Year 2015 concerning Second Amendment to Law Number 23 Year 2014 concerning Regional Government. 